\title{
DEEP IN THE BRAIN: Identity and Authenticity in Pediatric Gender Transition
}

\author{
SAHAR SADJADI \\ Amherst College \\ Paris Institute for Advanced Study \\ (iD) https: / / orcid.org/0000-0002-2004-4946
}

A children's book, Goblinheart:A Fairy Tale (Axel 2012), tells the story of Julep, who is born in a tribe where half of the youngsters grow wings to become fairies and the other half grow claws to become goblins when they come of age. Julep is surprised and unhappy when she grows wings. When asked by the elders of the tribe to join other fairies to tend to the leaves of a tree, Julep insists on staying with the goblins and tending to the roots, even though, without claws, digging proves hard work. When asked by a fairy how it is that Julep, who has wings rather than claws, is a goblin, Julep answers: "Because I am a goblin on the inside."

The book's author is the father of a transgender child who transitioned to live as a girl at age five. At a reading in New York City, he explained that he created Goblinheart to provide a tool for other children in a similar situation to make sense of their experience. In this story, as well as in a flurry of contemporaneous media accounts, authentic gender identity comes from inside, diverging from - and overcoming - the physical body and the uses, norms, and expectations associated with it. The story exemplifies the popularity and intelligibility of the interior origin of self and identity, which reverberated among the adults and youth I met during my research on clinical approaches to childhood gender variance in the United States. 
Throughout my fieldwork at children's gender clinics, expert meetings, and conferences in the United States between 2010 and 2012, and during subsequent follow-up research, I was intrigued by the hegemony of the interior origins of authentic self and identity and the rejection of possible external, including social, origins of identity. I found this consensus remarkable; perhaps because my ethnographic gaze originates from a context where narratives of the self are not anchored in a deep inner core but are relational and situational — what Afsaneh Najmabadi (2013, 277) calls a "self-in-conduct"_rather than self-referential. Moreover, the magico-spiritual undertone of the conversations I witnessed was striking, perhaps lending testimony to how mysterious these children who transgressed one of the most entrenched rules of their culture appeared. Statements about a child "born with the brain of the opposite gender" were articulated as self-evident facts by many clinicians, as well as by the media and some advocates. As a physician and anthropologist of medicine, I had begun this project as a critical study of a cutting-edge clinical field; I was perplexed by this merging of science, magic, and religion in explaining children's gender transition. As another example, I encountered the word soul in an article published by a team from a pediatric gender clinic at Harvard, who are pioneers of new developments in the field:

Male-to-female (MTF) and female-to-male (FTM) are terms recently replaced by many in the transgender community by affirmed female or trans-woman, and affirmed male or trans-man. This shift in terminology reflects the increasingly common belief that a transgender individual's gender does not change, as his or her brain (or soul) has always been his or her affirmed gender. (Edwards-Leeper and Spack 2012, 322)

This use of soul as interchangeable with the brain in the clinical literature is remarkable. It raises important questions about the contemporary scientific understanding of the brain, as well as the relation between the body and personhood that underpins the clinical practices surrounding gender-nonconforming and transgender children.

Below, I explore the epistemic and techno-scientific conditions of the emergence of clinical practices to identify, diagnose, and treat the true transgender child and adolescent and distinguish them from other gender-nonconforming children. I show how the current clinical enactment of gender identity has relied on processes of (psycho-)medicalization, individualization, thingification, and internalization. This article is based on a broader multisited ethnography of clinical practices around gender-nonconforming and transgender children in the United States. ${ }^{1}$ Here, how- 
ever, I focus on the history of the belief in and clinical search for the foundation of identity in the inner depths of the self, attempting to explain this cultural privileging of the internal and rejection of the external, including the social, as the origin of identity. I analyze contemporary scientific conceptualizations of the brain as the location of gender identity in relation to Western metaphysical conceptions of the body and the soul, and to modern accounts of the self as interiority and psychic depth. I engage with the ongoing nature-culture debate, the place of interiority in modern ontology, and the relation of science and materialism.

Over the past few years, an intensified concern for children's gender troubles has surfaced in the United States, and the field of clinical management of gender in children has rapidly expanded. The number of therapists specializing in the gender health of children is multiplying. The most renowned academic medical centers have established interdisciplinary pediatric gender clinics, particularly in response to the availability of puberty-suppression treatment for children diagnosed with gender identity disorder. At the same time, the American Psychiatric Association revised its manual of mental disorders, with the psychiatric category of gender identity disorder in children stirring controversies and ultimately remaining in the manual, before being renamed as gender dysphoria in 2013. The debates over the legitimacy of such a mental illness diagnosis for children continued through the process of the eleventh revision of the International Classification of Diseases by the World Health Organization. In this period, the media exploded with stories about transgender children and the possibility of medical treatment, and parent support groups formed around the country.

This new and sympathetic medicalization of childhood gender nonconformity developed on the heels of affirmative approaches that emerged in the late 1990s and countered an older paradigm that, since the 1960s, had discouraged cross-gender behaviors and interests in children. The primary recipients of these corrective treatments in earlier years were feminine boys who underwent behavioral modification therapies to promote masculinity, or psychoanalysis along with their family. These clinical practices were criticized for decades by feminist, gay, and transgender activists and scholars, progressive clinicians, and children's rights advocates for enforcing gender stereotypes and for their goals of preventing homosexual and transsexual adult outcomes (Bryant 2007). The last major clinic operating within this tradition in North America closed in 2015. Affirmative approaches, on the other hand, posit that children's gender variance is not a mental disorder, and distress is not inherent to it. It is a natural variation in the child's developmental trajectory and should be allowed to flourish without disparaging any potential adult outcome 
or pressuring the child toward conformity (Menvielle, Tuerk, and Perrin 2005). The affirmative clinicians offered supportive counseling mainly to parents - and sometimes to children - to cope with stigma and anxiety. Some of the early affirmative clinicians understood the condition of gender-variant children as unfolding toward an adult gay outcome. Some others, whom I interviewed and observed, moved toward the position of supporting the child regardless of the future outcome, encouraging parents to accept and cope with the uncertainty of the future. During this period, a small number of young prepubertal children began to transition, often following parents' and clinicians' realization that the young people's gender distress diminished when dressed and treated as the other gender. ${ }^{2}$

While the affirmative approach was taking hold in the United States, the field underwent another major transformation in the late 2000s with the arrival of medical treatment known as "puberty suppression" for transgender children. Children diagnosed with gender dysphoria or recognized as transgender are offered agonists of Gonadotropin Releasing Hormones (GnRH) at the pre- or early pubertal stage (often ages nine to thirteen) to suppress puberty as the first step to transitioning to the desired sex. The treatment aims to achieve a gender-congruent adult physical appearance, prevent the distress of puberty and to allow more time for decision-making about gender transition (De Vries and Cohen-Kettenis 2012; Mahfouda et al. 2017). During their years on puberty blockers, adolescents' genitals and reproductive tracts remain in a pre- or early pubertal state, and the pubertal growth spurt is suppressed. If followed by steroid hormones to achieve the physical characteristics of the other sex - as has been the case with almost all the patients from the clinics that have published reports (De Vries et al. 2011) - the reproductive tract never matures, eliminating the possibility of reproduction. Halting puberty, a systemic growth phase beyond sexual maturation, has consequences, for instance for bone density: GnRH receptors have been found in organs as varied as the skin and the heart, and the possible effects of puberty blockers on the brain and cognitive development currently remain unclear. ${ }^{3}$ Nonetheless, puberty suppression rapidly gained popularity and legitimacy, hailed as a breakthrough in the clinical management of children diagnosed with gender dysphoria. ${ }^{4}$ Younger children's social transition remained controversial, however (WPATH 2011).

Clinical approaches that support early medical interventions as a component of children's gender transition are often based on the notion that transgender children are born with the brain of the opposite sex and, hence, that their gender identity is immutable and in need of affirmation through medical transition. Proponents of this view argue that the immense tension between the gender identity 
of the child's brain and the child's sexual anatomy leads to distress and high risk of suicide and self-harm. Therefore, these children need to be treated before puberty sets in. (Later in this article, I will explore the clincial conceptualization of the relation between the self and the body that has led to understanding puberty as dangerous for children with strong cross-gender interests and desires.) This situation has created a diagnostic conundrum, given the knowledge that many gay adults had gender-nonconforming childhoods. The desire to know if a child, as young as four or five years old, is on a gay or transgender trajectory has constituted one of the main challenges for clinicians and principal sources of anxiety for parents. The recent availability of puberty suppression as treatment for transgender children has intensified diagnostic efforts, in order to distinguish the true transgender child from the gay-to-be child before puberty.

It is the interior origin of the condition that sets the transgender child apart from other children with gender-atypical behavior, clinicians who treat transgender children emphasize. Dr. Diane Ehrensaft, a prominent affirmative psychologist and creator of what she describes as "true gender self therapy," after emphasizing the innateness of gender identity and locating the site of true gender self primarily in the brain, argues: "Once we are born, the true gender self is most definitely shaped and channelled through our experiences in life, but its center always remains our own personal possession, driven from within rather than without" (Ehrensaft 2011, 79). The authors of The Transgender Child, widely seen as a formative text for parents and professionals, state that transgender children's gender identity does not match their assigned gender; they differ from gender-nonconforming children, since in the latter case "their (inner) gender identity" aligns with their biological sex, while only "their (outer) expression of gender" (Brill and Pepper 2008, 29) does not. However, in explaining how this inner true identity is revealed, the authors refer to one of the prominent clinicians in the field who emphasizes bathroom behavior, swimsuit aversion, toy preference, and "what type and style of underpants kids select (does your son want the girl-cut panties with flowers on them?)" (Brill and Pepper 2008, 3). This tension between identity and behavior or interests, and the effort to diagnose the true transgender child (or previously the child with gender identity disorder) whose identity, beyond behavior, diverges from their assigned gender, has haunted the clinical field since the outset.

\section{THE BRAIN, AUTHENTICITY, AND UNDERWEAR}

"She has changed her name from Arnold to Ariel," the fellow at the pediatric endocrine gender clinic reported to the rest of the clinical team, ${ }^{5}$ after visiting 
with the fourteen-year-old patient. "The family has started using female pronouns at home and she went shopping with her sister. She is wearing lipstick. She has not yet transitioned at school." The fellow continued her report by adding that, during her physical examination of Ariel to ascertain her stage of puberty, she noticed that Ariel was wearing a pink bra but men's underwear. Confusion spread across the faces of the clinicians. This last piece of information did not align with everything else they had just heard. They exchanged a few sentences about Ariel's history. They were at an impasse and could not decide whether to give the green light for her hormonal treatment. Time was passing in the room, and they needed to move on to the next patient. The whole clinic came to a standstill over Ariel's underwear.

I, who rarely ever said anything in an attempt to be as unobtrusive as possible at the clinic, suddenly heard myself saying: "I know women who wear men's underwear." The endocrinologist and the head of the clinic looked at me with surprise. The others laughed. Then he asked me: "Do you mean boxers or briefs?" The fellow indicated that Ariel was wearing briefs, and the endocrinologist looked a bit helpless. They kept wondering what to do with the underwear dilemma. I spoke up again: "Isn't it uncomfortable to fit the penis and the testes into very feminine and small underwear?" This possibility captured their attention. The psychologist responded: "It is a good point, but some of the kids do tuck them up even though it is uncomfortable. They can't stand boys' underwear; it reminds them of what they hate." I imagined Ariel just putting on whatever clean underwear she found when getting out of the shower and running out, unaware of what crisis her underwear would stir for these esteemed clinicians. The endocrinologist said to the two medical students that "this is a very interesting case who identifies as female but wears male underwear." He paused and added: "Underwear is the core, because it shows what they feel inside when they are not showing it to the outside world."

How did these expert clinicians come to ponder the meaning of underwear in diagnosing core gender identity? Gender identity, as the psychological sense of maleness or femaleness, was the conceptual invention of the psychiatrist and psychoanalyst Robert Stoller and an intervention into John Money's concepts of gender and gender role. Money, one of the most well-known sexologists of the twentieth century, used the word gender for the first time in 1955 in the phrase gender role, defined as "all those things that a person says or does to disclose himself or herself as having the status of boy or man, girl or woman, respectively" (Money 1955, 254). ${ }^{6}$ Gender role also included "erotic practices" and "the person's own replies to direct inquiry" (Money, Hampson, and Hampson 1955, 302). Money suggested in his early work that gender acquisition occurred prior to age two. In the 1960s, 
Stoller divided Money's unitary concept to distinguish behavioral aspects and social expectations about gender from the individual's psychological sense of self, partially in an attempt to explain the condition of his transsexual patients and to distinguish them from transvestite individuals. He named the outcome of Money's critical period of gender acquisition in the first eighteen months of life core gender identity, as a stable essence of every individual (Stoller 1964; Germon 2009). By differentiating between gender role and identity, Stoller anchored gender to some core or essence beyond the mundane behaviors and roles that might be subject to changing social norms. ${ }^{7}$ Although he was primarily theorizing within a psychoanalytic paradigm, Stoller suggested the possibility of biological forces involved in the core gender identity, a drive from inside the organism that possibly emanated from the endocrine and central nervous system. Money's concept of gender as an attribute of an individual, as something one has, markedly differed from later conceptualizations of gender by feminists from the 1970s onward, as a relation (Holter 1970), a system (Rubin 1975), an analytical tool (Scott 1986), or later as performative (Butler 1988). But it is this sexological concept of gender that is currently deployed in the clinical and public understanding of gender identity and transgender.

The emergence of the concept of gender identity was entangled with the clinical study and treatment of gender-nonconforming children. Stoller, together with Richard Green, led the clinic at the University of California, Los Angeles, where the first systematic institutional clinical engagement with feminine boys developed in the 1960s. Their treatment approach consisted of promoting masculinity in the child by behavioral modifications to reinforce masculine behavior, such as comportment and gestures, asking parents (and the therapist) to point out to the child when they observe "girly" walking, sitting, or use of hands - and then to instruct the male child how to modify and eliminate these gestures. They recommended removing toys and clothes associated with the opposite sex, participation in aggressive athletic activities, more interaction with male peers and less with female peers, and more time spent with the father. The cause of the problem in this paradigm was assumed to be an overly domineering, controlling, and mannish mother and a timid, weak father; the family therapy intervention had the goal to reset the power balance by encouraging the mother to defer to her husband in a more traditional role (Bryant 2007). Those clinical practices and the availability of the concept of gender identity led to the introduction of the diagnostic category of Gender Identity Disorder of Childhood in 1980, which was added to the third edition of the Diagnostic and Statistical Manual of Mental Disorders (DSM-III). 
In the case of Ariel, on the other hand, the clinicians were concerned about the inadequacy of her femininity for a definite diagnosis of female gender identity and a successful gender transition. While these clinicians shared the corrective paradigm's conceptualization of gender dysphoria as a distressing tension between the body and identity within a strictly binary gender order, they understood it primarily as a neuroendocrine condition and they differed in their proposed treatment and solution. This pediatric gender clinic, where I conducted fieldwork during 2010 and 2011, was one of the first to medically treat transgender children in the United States with puberty blockers (they offered steroid hormones for older adolescents). ${ }^{8}$ During the previous visit, Arnold was not yet using a female name or pronoun and was wearing basketball shorts. This lack of effort to look feminine had concerned the psychologist, who found Arnold androgynous, even leaning more toward the masculine. She explained to the clinical team that, as a child, Arnold was interested in gender-neutral activities and sports. Most of his friends were boys. By these measures, his childhood did not meet the clinic's expectations of transgender children. Arnold expressed the wish to become a woman, sometimes dressed in feminine clothes privately, and was disturbed by puberty, especially by getting taller and the deepening of his voice. Neither Arnold nor his father, who accompanied him, felt certain about what they wanted from the clinicians. The psychologist had suggested to them that they begin using a female name and pronoun and have Arnold present as more feminine before proceeding with any medical treatment.

The clinicians needed to agree on the diagnosis of gender identity to decide whether a child or adolescent was truly transgender and could receive treatment. In the guiding discourse of gender at the clinic, gender identity was located in the brain; the genitals (and, more broadly, sex) proved insignificant in diagnosing gender identity (while very significant for any future treatment plan). ${ }^{9}$ But how to access the gender identity of the brain? In practice, even though the clinic adhered to the theoretical separation of role and identity, the main tool used to confirm gender identity was the alignment of name, pronoun, and appearance (including clothing and gestures) in the direction of masculinity or femininity (judged by clinicians and shaped by the cultural standards of the clinic's white, straight, upper-middle-class milieu). Objects of clothing were imbued with meanings that could lead the clinicians to the true gender identity; the child's choice of clothes signaled their inner truth of gender. A crisis in the clinic occurred when the children or adolescents did not care about changing their name or pronoun and outfit, or when they chose gender-neutral names or clothes, or when different items of clothing they wore varied in their gender symbolism. The belief in the existence of a gender identity 
within every individual as the origin of gender served as a principle to align all the material contradictions that were then perceived as signs and manifestations of the underlying entity of a core/true/inner gender identity (residing in the brain), rather than constituents of gender in themselves. This alignment occurred under the guiding clinical goal of making a coherent sex/gender (believed by clinicians to be the actualization of an already existing coherent gender identity) with the pragmatic rationale of easing the patient's life. ${ }^{10}$ In this paradigm, the genital loses significance, but the underwear — paradoxically covering but revealing sex/gender through shape and style - gains it.

Most anthropological theorizing of clothing has revolved around its sociocultural meaning, through recognition and apprehension by others. Dress is not only a medium of communicating identities to others but constitutes these identities "in ways which we are compelled to conform regardless of our self-consciousness or even contempt" (Turner 2012, 487). Marshall Sahlins (1976, 203) writes: “The clothing system in particular replicates for Western society the functions of the socalled totemism" that makes possible "apprehending others, their social condition, and thereby their relation to oneself on first glance." Gendered clothing thus works to ensure recognition by others as man or woman, boy or girl, "on first glance." This is precisely why in the clinic underwear gains a privileged status as sign of gender identity (and not gender role) over other pieces of clothing. It is (presumably) not seen by others, and therefore devoid of social relations and concerns for how to present oneself to the world. It is relegated to the realm of individual interiority. At the same time, it is an artifact worn on the body, available to the clinical eye. It is a boundary object where the opposition between the external and internal of the body, between the social and the personal, becomes marked. Underwear thus becomes the signifier of truth of gender identity and a shortcut to an authentic interiority untouched by external influence. To recall the endocrinologist's pronouncement: "Underwear is the core because it shows what they feel inside when they are not showing it to the outside world."

If the case constitutes a true transgender case, the clinic psychiatrist explained to me, then transition should not be externally motivated. A negative affect attached to the external, including the social, was palpable in the affirmative accounts of identity that I encountered during my fieldwork. ${ }^{11}$ Fifteen-year-old Leigh explained to me emphatically that she did not believe her being transgender was a result of social factors; she was sure that her sense of being a woman came from inside, not outside. In such accounts, the social becomes cast as external, and to invoke external influence is perceived negatively, even akin to questioning the au- 
thenticity of the individual's identity and trivializing it. It may also stir troubling concerns about the mutability of gender (or, in other contexts, sexual orientation) that could be exploited by projects that attempt to pressure the minority to conform to the norms of the majority. The claims to a deeply rooted internal origin of (gender) identity have also undergirded successful legal strategies deployed in the courts in the pursuit of transgender rights. In fact, this ideological framework is becoming a near requirement for transgender rights. Clinicians are frequently invited to courts to testify to the true (trans)gender identity of their patients. In the case of Doe v. Yunits (2000), the court's ruling in favor of a transgender student and against her school was decided on the basis of the student's right to dress in accordance with her deeply rooted female identity, what the ruling called her "quintessence," rather than the right of any and all to wear gender-atypical clothes.

\section{THE INWARD TURN}

Anthropologists have long observed that the modern Western sense of the self as a bounded, coherent, internal depth denotes a peculiar, far-from-universal idea (Geertz 1974; Mauss 1985; Strathern 1988). More recently, a number of ethnographic studies of sexual and gender identities in Japan, Indonesia, India, and Iran depict cultural notions of identity and self that are more contingent, "on the surface," situationally and socially oriented rather than rooted in a deep stable inner essence (Kondo 1990; Boellstorff 2005; Reddy 2005; Najmabadi 2013). Historians have traced the emergence of the modern self as an innate core characterized by interiority, depth, and stability to the late eighteenth century in Britain, Western Europe and, a few decades later, in the United States. According to Dror Wahrman (2004), as British subjects in the colonies began to assert their own distinct identities over and against those of the metropole, particularly during the American Revolutionary War, anxieties produced by the flux of old categories — in part made possible by the rise of empire and encounter and racial mixing with populations with different gender relations — intensified and led to an embrace of more stable, rigid, and internally oriented identities.

In the United States, the inward shift took place a few decades later than in Britain. Early public education, as well as early American liberalism, was profoundly shaped by moderate Protestantism, many elements of which formed the foundations of a secular American culture. Children proved crucial to the project of nation-building and the expansion of the U.S. empire, as well as to the cultivation of liberal Protestant values (Sánchez-Eppler 1996; Block 2012). Children were also central to liberal theories of human nature in the eighteenth and nineteenth centu- 
ries. ${ }^{12}$ Among competing ideologies of childhood and child-rearing, the notion of the naturally developing (Anglo-American) child began taking hold in the writings of reformers and educators in the United States in the mid-nineteenth century. ${ }^{13}$ This era saw an emphasis on the inner life of the individual, on motives that guide and move from within rather than from outside, and on qualities that were not evanescent but fixed and stable (Block 2012). Society and its influences over the individual were cast as negative and rife with temptations or obstacles. This negative affect toward the external, including the social, available in the American cultural repertoire, has intensified in certain historical periods and is palpable in the contemporary United States. The historical shifts in the Euro-American notion of the self in tandem with the fluxes of imperial stability and instability invite us to think about the current regime of identity in the United States, with its retreat into the self and investment in ontologically fixed and innate identities, in relation to the crisis of U.S. empire.

The self, if true to itself, is thus perceived as inherently good and trustworthy. Tautological phrases such as "be yourself," a common piece of adult advice given to children, capture this culturally commonsensical belief and mistrust of external forces. Such articulations of the true self do not recognize power relations and how they differentially enable and uphold the self. One of the prominent clinicians of the field explained to me in an interview that she believes every child is born with a unique true gender self, and what we need to do is to allow that to flourish. Describing herself as a nature-nurture-culture integrationist, she found social construction theories of gender inadequate in explaining how individuals experience their gender as deeply seated within. ${ }^{14}$ While such clinicians are compassionately engaged in an effort to open a cultural space for conceiving of and accepting gender-atypical children, they are not equipped to account for the sociocultural conditions that have produced the marginality of these children given their internal, individual, and universal notion of the self. This account of gendered self cannot, for example, explain the true gender self of the little masculine bully (bullying is a major problem in the lives of gender-variant children) or many forms of toxic masculinity among adolescents currently in public debate. Are they also true gender selves, and will boys be boys? The ideology of true self and the essentialization of identity runs deep in contemporary American culture, and given its lack of a theory of power, can be mobilized across the political spectrum. ${ }^{15}$

\section{SEX OF THE SELF}

Sex, as one of the main markers of identity, occupied a central place in this inward turn. While the anchoring of sex in biology preceded that of race by a 
century, both sex/gender and race underwent similar transformations at the end of the eighteenth century from fluid to rigid and became thought of as natural and essential (Wahrman 2004). This shift accompanied the development of clinical medicine at the end of the eighteenth century. Michel Foucault (1973) illustrates the rise of a new spatialization of disease on/in the body of the individual in this era, and the development of a range of techniques of perception to make the invisible visible and the interior revealed. In classificatory medicine, disease is given an organization outside the body, and classification is a flat structure without depth. In anatomico-clinical medicine, disease is located in the body and the gaze turns toward individuality and depth.

Geertje Mak's praxiographic (see Mol 2002) historical analysis of nineteenth-century hermaphrodites in Western Europe demarcates a dramatic historical shift in clinical conceptualizations of sex "from something primarily touching the sexed moral, economic and social order in which a person was inscribed, to something troubling an individual person's self in relation to her body" (Mak 2012, 230). This shift was enabled by physicians' greater access to naked bodies and to internal organs at the end of the nineteenth century, as well as the development of medical techniques that enabled the enactments of bodily sex through the dislodgement of the body from the person (e.g., samples of gonadal tissue in the laboratory). Later, at the turn of the twentieth century, the hermaphrodite individual's subjective wish and sense of self became new objects of study. Consistency between appearance, social role, and sense of self became the new clinical goal, made possible by surgical advancements of the time. What Mak $(2012,10)$ calls "sex of the self" emerged in the later decades of the nineteenth century, gained increasing sway through developments in psychology and psychiatry in the twentieth century - including an understanding of oneself as inhabited by an interior psychological space (Rose 1990) — and came to be called gender identity in the mid-twentieth century.

Currently the self (gender identity) has gained full independence from and primacy over the body in affirmative gender clinics, but only as far as the medical technology can alter the body and appearance to align with the self. For transgender individuals, there are no atypical internal physical organs (unlike the case for individuals with intersex conditions) to partly anchor the true sex/gender; hence the search for the interior of the individual is primarily the search for the self, and the tension is a full-fledged one between the self and the body. The sexological concept of gender identity has facilitated the separation of the sex as self from sex as body, as well as the reification of the sex of the self as a thing inside the person, 
prior to social/external forces. ${ }^{16}$ Current psychoscientific trends allocate this thing to the brain.

\section{BORN THIS WAY AND THE IMMATERIALITY OF THE BRAIN}

Among the different actors involved in treating gender-variant children, there is consensus that gender dysphoria (previously gender identity disorder) has some neuroendocrine cause, even if it is only partially responsible and even if the studies and the evidence are, as of yet, inadequate. Often these claims are uttered as convictions, as obvious established truth, without any reference to any studies or detailed medical explanations. When the clinicians and advocates do attempt scientific explanation, they often invoke the theory concerning the role of prenatal hormonal gendering of the brain in shaping gender identity. ${ }^{17}$ At the 2011 Annual Trans Health Conference in Philadelphia, during a period when the American Psychiatric Association was revising the Diagnostic and Statistical Manual of Mental Disorders (DSM) for its fifth edition, the only session that advocated for the removal of the diagnosis of gender identity disorder from the DSM ended by suggesting an endocrine category with the proposed title of Atypical Gender Identity Syndrome. The proposers (trans-health-care professionals concerned about access to medical care and insurance coverage) argued that recent studies of transgender people show the effect of fetal hormonal influence on the brain, leading to the development of a gender identity incongruent with the sexing of their anatomy.

This theory postulates that males and females are born with differently wired brains as a result of exposure to different sex hormones in utero. It developed and gained adherents from the 1950s until the 1970s, after which it was taken for granted as scientific fact in cognitive neuroscience and among other sex researchers (Jordan-Young 2010). The power of the theory, despite the lack of plausible scientific evidence to substantiate it, lay in the facile way that it spoke to old convictions about men and women's different characters and interests. The theory was proposed and expanded by John Money and his colleagues and students, most of whom were psychologists, hesitantly at first (given Money's emphasis on postnatal gender acquisition) and then more confidently. Rebecca Jordan-Young (2010) analyzed more than three hundred studies supporting this theory and demonstrated, among other things, that these studies do not measure the same variables or compare the same populations, and hence do not establish the empirical evidence for the theory that they claim to support.

Previously, this theory of innate male and female brain differences faced criticism from those committed to gender justice for its sexist implications and for 
naturalizing conventional gender norms. Today, however, many progressive scientists, clinicians, and advocates embrace it for its potential to offer what appears as a simple and essentialist account of transgender condition aligned with the popular cultural tropes such as "trapped in the wrong body" and "born this way." Having disrupted the alignment of gender interests and behaviors with biological sex, the transgender person has paradoxically become of interest to scientists as the site for research on the "biology of gender identity." Within this paradigm, there are two parallel essences - the sex of the body and the gender (identity) of the braincorresponding to each other in most people and clashing in a small minority of people. Alternative accounts of becoming (trans)gender and the insights of radical transgender thinkers remain marginal to this mainstream cultural and clinical discourse. For example, decolonial and trans of color scholars address the histories and ways of being gender-variant that the hegemonic Euro-American notions of sexual/gender identity exclude (Dutta and Roy 2014; Green and Bey 2017; Snorton 2017); the writer Andrea Long Chu (2018) writes about "the notion that transition expresses not the truth of an identity but the force of a desire," while the artist Rosza Daniel Lang/Levitsky's biographical statement often includes the phrase "identifies with, not as."

The recent locating of gender identity (sex of the self) in the (universal) brain has not overcome the dualism of the sex of the body and sex of the self. Rather than materializing the self, this association of the self with the brain has idealized (indeed, dematerialized) the brain as something different from the body, leading transgenderism to be understood and described as a conflict between the brain and the body. This understanding of the soul or the mind (here, the brain) as a thing behind a person's physical appearance has run through Western metaphysical thought since Plato. A variety of soul-body dualist theories have emerged in the history of ancient and modern philosophical, religious, and medical thought, with different accounts of the interaction between the soul and the body. ${ }^{19}$ Christianity, with its emphasis on the idea of substance dualism (ontological distinction between the body and the soul) decisively enforced the idea of the human being as fundamentally a soul that initiates action through body in the manifest world. ${ }^{20}$ The dualism that appears in the contemporary clinical conceptualization of the transgender identity is, similarly, premised on the distinction between the body and brain and the superiority and primacy of the brain, as the locus of identity, in determining gender. There are older sexological accounts of inversion such as Karl Ulrichs's concept of an Urning (in English, Uranian), in which a female psyche in a man's body is portrayed as a positive and even noble state of being. ${ }^{21}$ In this dualist 
account, the sex of the body and the sex of the self can diverge but cohabit. But the dualism of current clinical accounts of transgenderism does not deem such cohabitation tenable. Instead, it strives for coherence, unity, and wholeness as the ideal and healthy state of being, with the intervention and help of medicine. It is within this dualist discourse of body and identity, premised on the superiority of the soul/mind/brain, that the view of puberty as the body's betrayal of the brain (in gender-variant children) enjoyed a smooth cultural and scientific reception.

"Born this way" currently dominates the clinical and popular (progressive) accounts of gender and sexual identities. The authenticity of the self relies not only on its interiority but also on its innateness, on having been always so. As one of the pioneers of puberty-suppression treatment of transgender children has explained: "I like the term affirmed rather than trans, because a person cannot really transition to something he already is. In other words, how can you be a male to female if you really always were a female in your brain?" (Spack 2009, 312) This striking denial of becoming anything other than what one has always been, resonating with certain culturally rooted doctrines of predestination, accompanies and sustains the dictum of "born this way." The claim to the innateness of the condition of transgender children joins the claim to the naturalness of gender variance. The medical history of sex/gender disorders has been heavily shaped by the cultural and theological invocation of the unnaturalness of sexual deviance. ${ }^{22}$ What nature stands for in these debates is largely about morality, even when, as early as Thomas Aquinas, zoological evidence was selectively marshalled for proving the naturalness of dominant sexual ethics. Straddling the moral and the ontological, "born this way" recuperates sex/ gender deviation on the side of the natural, thus good, through claims to its innateness.

Under persistent conditions of inequality and stigmatization, innate biological explanations for sexual or gender deviation absolve individuals of moral blame, ground the minority condition in ontological difference, and endow the self with authenticity, legitimacy, and stability. ${ }^{23}$ Many parents of gender-variant children, facing social reprimand and at times their own ambivalences, embrace the "born this way" discourse that not only renders their children innocent but also exonerates the parents of blame, unlike the older psychoanalytical paradigm of early psychosexual development, which focused on deficient gender roles and parentchild relations, upholding cisgender heterosexuality as the healthy outcome. This discourse also responds to the religious Right's rhetoric of choice in the United States, employed to deny equal rights to LGBT individuals. At the same time, the appeal of innate notions of identity exceeds the exigencies of this political tactic. 
Beyond this specific study, such paradoxical quests for authenticity and individual self-making by discovering the truth of self with which an individual is born are relied on more broadly to define identities in the contemporary United States. ${ }^{24}$

\section{NATURALNESS OF IDENTITY AND INTERIORITY OF NATURE}

The naturalist discourse of the affirmative approach to gender-variant children privileges interiority as the site of naturalness and authenticity of difference. Questioning modern Western understandings of the relation between nature and culture, scholars have employed terms such as naturecultures (Haraway 2003) and worlding (Haraway 2008; Tsing 2010) ${ }^{25}$ to overcome the dualism of nature and culture, emphasizing the entanglement of these terms and of the human and nonhuman. While much of this scholarship has challenged a cultural notion of nature that remains exterior to humans, I have found in my research a cultural allocation of nature to interiority. This is not the interiority of nature that, for example, reckons with the bacteria in our guts, but one that transcends the human body and thus distinguishes humans from other species. Philippe Descola (2013, 173; emphasis mine) describes modern ontology as naturalist in opposition to other ontologies such as animism and defines naturalism as "the continuity of the physicality of the entities of the world and the discontinuity of their respective interiorities." Marshall Sahlins $(2014,289)$, in response, emphasizes the abundance of anthropomorphism in modern culture in endowing a range of institutions, organic, and inorganic beings with human characteristics. Hence he questions the existence of a radical difference between naturalism and animism when it comes to anthropomorphism, asserting: "We are one of the others." This anthropomorphism within modern naturalist ontology extends to scientific entities: the brain appears as fetish, imbued with omnipotent explanatory power.

Within the new materialist scholarship of the past few years, much enthusiasm has been directed toward the material and the natural, partly in response to the ruling idealism of discourse and language in the past decades and the humanist and anthropocentric tendency of social theory to reduce the material world to an effect of human culture. Within social studies of science and technology, commentators have articulated this move as an invitation to a more open interdisciplinary engagement with the sciences. But one should avoid a careless equation of nature, materiality, and science, or the distribution of matter-idea along the axis of nature and culture. Nature is a cultural idea at times located far from the materiality of nature (Kirby 2008). In fact, the idea of nature in Western modernity, as an all-encompassing, infinitely omnipotent, and inherently good being, is deeply enmeshed 
with Christian thought. ${ }^{26}$ The abstraction of gender into the idea of gender identity and its reification as a thing in the brain is occurring at a time when neuroscience (and the popular-science version of it) has become one of the front-line scientific disciplines of our time (Dumit 2004; Vidal 2009; Martin 2010). The return to science as a way of understanding human social phenomena does not always mark a materialist turn and, as the current phantasmatic deployment of the brain in conceiving identity shows, can constitute an extension of extremely idealist thinking: a pseudomaterialism, in a sense.

I propose that the predominance of gene and brain talk in explaining identity relies less on the appeal of biological explanations per se than on a certain biological explanation that locates sources of identity or human differences within the sovereign individual. The biology that engages with what remains external to the human individual (the environment) is rarely invoked in these debates. In fact, faith in innateness and interiority, such as the hard-wired brain as a result of hormonal influence prior to birth, is taken to establish the veracity of identity, even despite biological evidence to the contrary. Similarly, when people emphasize the naturalness of gender or sexuality, they are not interested in the role of air and water, trees and bacteria (elements of nature) in shaping these dimensions of human life across various histories and geographies. I suggest that the particular spatialization of the gene and the (hard-wired) brain inside the body (of the individual), and their temporality extending backward, prior to social life, make them powerful and appealing explanatory entities. Perhaps it is not surprising, then, that the brain could be replaced by the soul in the scientific paper I cited at the beginning of this article. The soul, too, has both of these spatial and temporal features: interiority and innateness. ${ }^{27}$

The burden of revealing innate human characteristics presumed to be natural has long been placed on children, who have occupied a particular place in modern Western thought in relation to notions of the authenticity of identity. The temporal politics surrounding adults' relation to children is not just that of orientation toward the future (Edelman 2004). Children are also imagined as the past of adults - carriers of seeds of adult identity. Stanley Hall $(1886,131)$, a major theorist of childhood and adolescence in the late nineteenth and early twentieth centuries, believed that the study of childhood "is likely to give us at last what we have longed for for a great while-something like a perspective, that will enable us to distinguish the deeper and older things of the soul from those that are of recent acquisition." ${ }^{28}$ This spatial ("deeper") and temporal (“older") search for what is foundational to human nature/soul — that childhood is tasked to offer against 
what is of "recent acquisition" _ evinces the same desire that currently drives the search for the truth of identity in the brains of gender-nonconforming children.

It appears to me that what is counterposed to the sociocultural in the contemporary debates over gender and sexual identity is not natural and biological but, more precisely, the individual and the internal. Or, in other words, a particular cultural notion of nature and biology is invoked to restore to the self some essence beyond and before human interaction with the environment. The nature/culture dyad becomes reconfigured as internal/external - the natural is conceived as internal, innate, and thus authentic, while the cultural is framed as external, malleable, and thus spurious.

\section{CODA: Considerations for Reframing Children's Gender Discontent}

Current accounts of gender identity as a thing inside the brain of the individual, an essence prior to (and even bereft of) the bodily and social production of gender, advance an idealist ontology of human nature even as they invoke scientific language and inhibit any alternative materialist analysis of children's gender troubles. These accounts, for instance, cannot explain the fact that Ariel's clothing did not neatly align in the direction of femininity or masculinity other than as a sign of dubious identification. Nor can they account for the role of racial economies of masculinity and femininity in the United States - historically feminizing Asian Americans and masculinizing African Americans - in enabling what some clinicians deemed a more successful transition to womanhood for the Asian teenager than for the Black adolescent. In addition, the notion of an innate immutable gender identity of the brain does not allow for, and finds inauspicious, the situatedness and temporality of gender: transition without a history of early childhood gender dysphoria, transition motivated by the desire to belong to a community, or retransition all come to lack authenticity. ${ }^{29}$

The contemporary appeal of the interior stable essence as the authentic origin of identity, deserving of respect and rights, constitutes a cultural tendency that has surfaced and intensified during a historical juncture in the United States in which imperial hegemony is waning and domestic conditions are marked by precarity as well as social and political crisis. During my fieldwork, when realizing my Iranian origins, professionals and advocates frequently asked me about gender transition in Iran, where the state institutionally supports medical transition for transgender people. My puzzled U.S. interlocutors often found Iranian transgender people both peculiarly fascinating and, paradoxically, proof of a universally shared biological mechanism ("even in Iran”). While many immediately and openly won- 
dered about gender transition in Iran in the context of women's oppression there, they understood gender dysphoria and transition among American transgender youth as an individual inborn trait, unrelated to (unequal) gender relations or any other social relations. This inability to situate individuals in their environment and within the power relations that govern the cultural-historical particularities of U.S. society led to inadequate accounts of becoming gendered and to narrow prescriptions for gender discontent.

To care for the well-being and health of gender-subversive children and their reproductive rights demands an approach to the child's body in its entirety, not solely in its gender symbolism as a vehicle for sacred notions of transcendent identity. Puberty, then, does not have to be imagined as an inevitable natural disaster ravaging the child's body and body-brain integrity from within, to be averted at any cost. In that case, gender transition would not require claims to the essence of identity. An alternative materialist account could enable an approach to children as body-subjects growing as part of and in interaction with their environment and its many forces, people, objects, and ideas - and their histories. Such an account would allow for the possibility that the categories of personhood of the future and their relation to each other and to the body might not be those of today and, perhaps, have yet to emerge.

\begin{abstract}
Based on an ethnography of clinical practices around gender-nonconforming and transgender children in the United States, this article explores the cultural and scientific notions of identity that shape this field. It examines the practice of diagnosing true gender identity in the clinic and situates the search for the foundation of identity in the inner depths of the self, and in children as harbingers of authenticity, as part of a broader cultural history. It addresses the scientific substantiation of the faith in innateness ("born this way") and interiority ("from within") of identity, as well as their political appeal. This article challenges the often taken-for-granted association of science with materialism - and the distribution of matter-idea along the natureculture axis - by demonstrating the idealism that drives the siting of identity in the brain. Finally, it questions the assumption that it is the appeal of nature and biology that underlies the cultural attachment to entities such as the gene and the brain as locations for the origin of identity in the contemporary United States. Rather than the nature-culture dyad, this article argues that the internal-external dyad more accurately captures and explains this cultural attachment. [transgender children; brain; identity; materialism]
\end{abstract}




\section{NOTES}

Acknowledgments Thanks to Carole Vance and Miriam Ticktin for their generous feedback on this article, and to Rebecca Jordan-Young for comments on an earlier version. Careful engagement and suggestions from four anonymous reviewers and both past and present editorial teams at Cultural Anthropology, especially Brad Weiss, made this a better article. I am grateful to many colleagues, mentors, and friends for generative conversations throughout the development of the larger project on which this article is based. Fieldwork for this research and writing of this article were supported by the Wenner-Gren Foundation, the National Science Foundation, Amherst College, and the Brocher Foundation.

1. This article draws from a larger project on the study of the expert revision of the psychiatric category of Gender Identity Disorder of Childhood (GIDC) by the American Psychiatric Association for the DSM-5, and the diagnostic and treatment practices at two major pediatric gender clinics in the United States, one psychiatric and one endocrine. In one of the clinics, I observed the clinical interview and consultation with parents and children. In the other, I observed the four-to-five-hour meetings of the clinical team as they discussed the cases before and after the clinicians visited children and adolescents. My medical training played an important role in making this fieldwork and access to the clinics possible. My familiarity with medical settings facilitated my inhabiting the space of the hospital/clinic and engaging with the clinical debates. At the same time, I needed to emphasize and clarify to the clinicians that my project was an anthropological study of their practices and not a clinical study of gender-variant children, even though I was a doctor. In addition to fieldwork at the clinics, I observed parent support groups, a summer camp for gender-variant children, and various conferences and professional gatherings in the United States and Europe, and I conducted in-depth interviews with DSM-5 working group members, clinicians, and parents. The study also included research at the archives of the American Psychiatric Association. This project was conducted as a twentyfour-month multisited ethnography from March 2010 to March 2012, followed by complementary fieldwork during the summers of 2014, 2015, and 2016.

2. See Meadow 2018 for parents' narratives of young children's gender transition.

3. There have been no studies of the long-term physical side effects of puberty blockers among gender-variant/transgender children. The follow-up studies conducted by the first (Dutch) clinic that provided the treatment to twelve-to-sixteen-year-old adolescents report positive outcomes for psychosocial adjustment following full medical transition (De Vries et al. 2011, 2014). In recent years, however, there has been emerging evidence of severe near- and long-term skeletal and neurological adverse effects experienced by women who were treated for precocious puberty in childhood with Lupron (the same GnRH agonist commonly used with transgender children), which has been reported to the U.S. Food and Drug Administration as well as on patient forums (see Jewett 2017). The reported adverse effects of pediatric use of Lupron range from depression and seizure to degenerative disc disease, chronic pain, and bone fractures later in life. For further discussion of the consequences of the treatment for fertility and analysis of the ethical dimensions of the treatment, see Sadjadi 2013, Abel 2014, and Roen 2016. Parental consent is required for the medical treatment of minors. The treatment is expensive: Lupron cost around $\$ 15,000$ per year during my fieldwork and was rarely covered by insurance.

4. Puberty suppression bridged the affirmative and corrective approaches and some clinicians of the latter group also referred children who had not responded to psychological treatment for puberty blockers.

5. A fellow is a specialist (in this case, a pediatrician) who is training for a subspecialty (in this case, pediatric endocrinology).

6. This is the first time the word gender was used in print with a meaning near the manner in which it is used today. Prior to Money's intervention, gender had been only utilized to refer to grammar and linguistic classifications (Germon 2009).

7. Stoller, a psychiatrist and psychoanalyst, is better known for his conceptual split of sex and gender (see Stoller 1968). While Stoller's sex/gender dualism appealed to many fem- 
inists who then conceptualized gender in their own way, he in fact had imagined gender having a component that was an essence, simultaneously psychic and biological. For him, not only sex but also gender identity had essential biological causes.

8. In the clinic transgender was synonymous with medical transition, replacing the older term transsexual, rather than an umbrella term for all gender-nonconforming people.

9. Hating one's genitals, however, remains one of the hallmarks of official accounts of the true transgender child, even though during my fieldwork I found this sentiment to be rare among (prepubertal) gender-variant children.

10. In his ethnography of facial feminization surgery, Eric Plemons (2017) argues that a shift of focus from the genitals toward more visible parts of the body in trans-medicine marks a shift toward understanding sex/gender as a matter of social recognition. In my observations in the pediatric clinics during the same period as Plemons's research, this move away from the focus on the genitals was accompanied by a firm belief in the presocial essence of gender identity. Bodily modifications were deemed necessary primarily to align the body with identity, while also directed at achieving bodies in future that would be easily recognized as man or woman.

11. Such understandings of the (gendered) self vary across race and class differences (Valentine 2007). During my fieldwork, I observed that the individualization, internalization, and abstraction of gender identity was more readily embraced by middle- and upper-class Americans than, for instance, immigrant working-class families. In this article, however, I am exploring the ideas that underpin the dominant cultural and clinical discourses and practices around gender-nonconforming children.

12. For eighteenth- and nineteenth-century liberal theorists of human nature, (male) children became the central site for the resolution of the lasting dilemma in which the rational autonomous individual is both free and in harmony with the prevailing social order. In Liberalism and Empire, Uday Singh Mehta (1999) argues that understanding liberalism's relation to children is important to understanding political exclusions of liberalism and the acceptance of colonialism by British liberal thinkers such as John Locke and John Stuart Mill. The colonized, like children, were potentially equal to Europeans but not until they were civilized. Conservative thinkers such as Edmund Burke, however, believed in the radical alterity of the colonized and were skeptical of the civilizing mission.

13. Jean-Jacques Rousseau's romantic and naturalist view of childhood profoundly influenced these ideas. In his view, children were neither depraved (as Calvinists believed) nor a blank slate (as Locke believed), but born with innate human goodness, at risk of corruption by the outside world.

14. See Vance 1989 for a discussion of various (mis)interpretations of social construction, and Strathern 1988 for reflections on the assumed malleability and weakness of the cultural.

15. For example, American white nationalists such as Richard Spencer call themselves "identitarian" and invite a return to one's "real identity." For an elaborate discussion of the origin of identitarianism in European right-wing thought, see Williams 2017. Elucidating the relation between these liberal and illiberal attachments to self-identity, I suggest, demands a closer engagement with the effects of the shifts in U.S. imperial hegemony within the anthropology of neo/late-liberal culture.

16. For a discussion of thingification in philosophical and scientific thought, see Barad 2003. For a discussion of gender identity as a thing, see Fausto-Sterling 2012.

17. For examples of recent studies of the brain of gender-dysphoric children, see Nota et al. 2017 and Bakker 2018. For examples of clinicians' invocation of this theory, see Ehrensaft 2011 and Rosenthal 2014. The media abounds with references to prenatal gendering of the brain, beginning with the pivotal 2007 episode of the TV show 20/20, during which Barbara Walters brought transgender children to public awareness.

18. For scholarly debates about the relation between identity and the sexed body, transgender embodiment, and its medicalization, see Prosser 2006, Spade 2006, and Salamon 2010.

19. Thales, for example, believed that soul is something like the power of a magnet, rather than a substance in its own right. 
20. René Descartes's translation of this idea into rational terms, whereby the human being is composed of a thinking thing and an extended thing, was vehemently criticized by other German philosophers beginning with Immanuel Kant. It is notable that not all philosophical reflections on the soul share an exclusively internalist emphasis. Scholars have argued that Christian thought, as advanced by St. Paul and Augustine in particular, had a major internalizing effect on the soul, an innerness later consolidated by the Protestant movement.

21. Here, see the series of articles written between 1864 and 1880 and published in English as Ulrichs 1994. Ulrichs's conceptualization of homosexuality and the biological theory he proposed are very close to current popular and clinical understandings of transgender people.

22. See Boswell 1980, 303-332 for a further elaboration of Christian theology's invocation of nature as the base of its sexual ethics.

23. For a discussion of strategic invocations of the innate and immutable origins of sexual identity by the gay movement, see Jakobsen and Pellegrini 2004 and Walters 2016.

24. For instance, a similar trend exists in the popularity of genetic ancestry testing in the United States as a way for people to discover their true self and become who they have always already been (Abu El-Haj 2012).

25. Anna Tsing (2010) uses the term worlding to bridge the tension between anthropology's commitment to context and science studies' emphasis on actors. Donna Haraway (2008) has written about queer reworlding in reference to the normality of the human-nonhuman dichotomy.

26. In his critique of Descartes's understanding of nature, Maurice Merleau-Ponty (2003, 131) writes: "The concept of Nature is mixed with the concepts of God and human being in Cartesian thinking."

27. In his discussion of the totemic principle, Émile Durkheim invokes the soul as an example of a totem in Western thought.

28. Hall's work was guided by an influential late nineteenth-century interpretation of evolutionary theory that saw the development of the individual child as a reflection of the stages of human evolution, which compared children to savages.

29. Much to the surprise of the author of Goblinheart, shortly before he finished writing the book, his daughter retransitioned to being a boy at age nine. (For a trans-affirming account of young people's change of gender after the first transition, see Travers 2018.) I use the term retransition rather than the more commonly used detransition to account for time and for the entanglement of age and gender. One does not go back in time to a previous gender. Life circumstances change. A five-year-old boy is not gendered the same as a nine-year-old, nor does a forty-year-old woman experience gender as a twenty-year-old woman did two decades earlier. Retransition, unlike detransition, does not imply that the first transition was a mistake to be undone.

\section{REFERENCES}

Abel, Brendan S.

2014 "Hormone Treatment of Children and Adolescents with Gender Dysphoria: An Ethical Analysis.” Hastings Center Report 44, S4: S23-27. https: / / doi.org/10.1002/ hast.366.

Abu El-Haj, Nadia

2012 The Genealogical Science: The Search for Jewish Origins and the Politics of Epistemology. Chicago: University of Chicago Press.

Axel, Brett

2012 Goblinheart:A Fairy Tale. Illustrated by Terra Bidlespacher. Brooklyn: East Waterfront Press.

Bakker, Julie

2018 "Brain Structure and Function in Gender Dysphoria." Endocrine Abstracts 56, S30.3. https:/ / doi.org/10.1530/endoabs.56.S30.3. 
Barad, Karen

2003 "Posthumanist Performativity: Toward an Understanding of How Matter Comes to Matter." Signs 28, no. 3: 801-831. https://doi.org/10.1086/345321.

Block, James E.

2012 The Crucible of Consent: American Child Rearing and the Forging of Liberal Society. Boellstorff, Tom Cambridge, Mass.: Harvard University Press.

2005 The Gay Archipelago: Sexuality and Nation in Indonesia. Princeton, N.J.: Princeton University Press.

Boswell, John

1980 Christianity, Social Tolerance, and Homosexuality: Gay People in Western Europe from the Beginning of the Christian Era to the Fourteenth Century. Chicago: University of Chicago Press.

Brill, Stephanie, and Rachel Pepper

2008 The Transgender Child: A Handbook for Families and Professionals. San Francisco: Cleis Press.

Bryant, Karl

2007 "The Politics of Pathology and the Making of Gender Identity Disorder." PhD

Butler, Judith dissertation, University of California, Santa Barbara.

1988 "Performative Acts and Gender Constitution: An Essay in Phenomenology and Feminist Theory." Theatre Journal 40, no. 4: 519-31. https://doi. org / 10.2307/3207893.

$\mathrm{Chu}$, Andrea Long

2018 “On Liking Women.” $n+1$, no. 30. https://nplusonemag.com/issue-30/essays/onliking-women.

Descola, Philippe

2013 Beyond Nature and Culture. Translated by Janet Lloyd. Chicago: University of Chicago Press. Originally published in 2005.

De Vries, Annelou L. C., and Peggy T. Cohen-Kettenis

2012 "Clinical Management of Gender Dysphoria in Children and Adolescents: The Dutch Approach.” Journal of Homosexuality 59, no. 3: 301-320. https://doi.org/10. 1080/00918369.2012.653300.

De Vries, Annelou L. C., Jenifer K. McGuire, Thomas D. Steensma, Eva C. F. Wagenaar, Theo A.

H. Doreleijers, and Peggy T. Cohen-Kettenis

2014 "Young Adult Psychological Outcome after Puberty Suppression and Gender Reassignment." Pediatrics 134, no. 4: 1-9. https://doi.org/10.1542/peds.20132958.

De Vries, Annelou L. C., Thomas D. Steensma, Theo A. H. Doreleijers, and Peggy T. Cohen-

Kettenis

2011 "Puberty Suppression in Adolescents with Gender Identity Disorder: A Prospective Follow-up Study." Journal of Sexual Medicine 8, no. 8: 2276-83. https://doi.

Dumit, Joseph $\operatorname{org} / 10.1111 /$ j.1743-6109.2010.01943.x.

2004 Picturing Personhood: Brain Scans and Biomedical Identity. Princeton, N.J.: Princeton University Press.

Dutta, Aniruddha, and Raina Roy

2014 "Decolonizing Transgender in India: Some Reflections." Transgender Studies Quarterly 1, no. 3: 320-37. https://doi.org/10.1215/23289252-2685615.

Edelman, Lee

2004 No Future: Queer Theory and the Death Drive. Durham, N.C.: Duke University Press.

Edwards-Leeper, Laura, and Norman Spack

2012 "Psychological Evaluation and Medical Treatment of Transgender Youth in an Interdisciplinary 'Gender Management Service' (GeMS) in a Major Pediatric 
Center." Journal of Homosexuality 59, no. 3: 321-36. https://doi.org/10.1080/009 18369.2012.653302.

Ehrensaft, Diane

2011 Gender Born, Gender Made: Raising Healthy Gender-Nonconforming Children. New York: The Experiment.

Fausto-Sterling, Anne

2012 “The Dynamic Development of Gender Variability." Journal of Homosexuality 59, no. 3: 398-421. https:/ / doi.org/10.1080/00918369.2012.653310.

Foucault, Michel

1973 The Birth of the Clinic. Translated by Alan Sheridan. London: Tavistock. Originally published in 1963.

Geertz, Clifford

1974 "'From the Native's Point of View': On the Nature of Anthropological Understanding." Bulletin of the American Academy of Arts and Sciences 28, no. 1: 26-45.

Germon, Jennifer https://doi.org/10.2307/3822971.

2009 Gender:A Genealogy of an Idea. New York: Palgrave Macmillan.

Green, Kai M., and Marquis Bey

2017 "Where Black Feminist Thought and Trans* Feminism Meet: A Conversation." Souls 19, no. 4: 438-54. https:/ / doi.org/10.1080/10999949.2018.1434365.

Hall, Stanley

1886 "Modern Methods in the Study of the Soul." Christian Register 75: 131-33. Haraway, Donna J.

2003 The Companion Species Manifesto: Dogs, People, and Significant Otherness. Chicago: Prickly Paradigm Press.

2008 “Companion Species, Mis-Recognition, and Queer Worlding." In Queering the Non / Human, edited by Noreen Giffney and Myra J. Hird, xxiii-xxvi. Burlington, Vt: Ashgate.

Holter, Harriet

1970 Sex Roles and Social Structure. Oslo: Universitetsforlaget.

Jakobsen, Janet R., and Ann Pellegrini

2004 Love the Sin: Sexual Regulation and the Limits of Religious Tolerance. Boston: Beacon Press.

Jewett, Christina

2017 "Women Fear Drug They Used to Halt Puberty Led to Health Problems." Kaiser Health News, February 2. https://khn.org/news/women-fear-drug-they-used-tohalt-puberty-led-to-health-problems.

Jordan-Young, Rebecca

2010 Brain Storm: The Flaws in the Science of Sex Differences. Cambridge, Mass.: Harvard University Press.

Kirby, Vicki

2008 "Natural Convers(at)ions: Or, What If Culture Was Really Nature All Along?" In Material Feminisms, edited by Stacy Alaimo and Susan Hekman, 214-36.

Kondo, Dorinne K. Bloomington: Indiana University Press.

1990 Crafting Selves: Power, Gender, and Discourses of Identity in a Japanese Workplace. Chicago: University of Chicago Press.

Mahfouda, Simone, Julia K. Moore, Aris Siafarikas, Florian D. Zepf, and Ashleigh Lin

2017 "Puberty Suppression in Transgender Children and Adolescents." Lancet Diabetes and Endocrinology 5, no. 10:816-26.https:/ / doi.org/10.1016/S2213-8587(17)300992.

Mak, Geertje

2012 Doubting Sex: Inscriptions, Bodies, and Selves in Nineteenth-Century Hermaphrodite Case Histories. Manchester, UK: Manchester University Press. 
Martin, Emily

2010 "Self-Making and the Brain." Subjectivity 3, no.4:366-81.https://doi.org/10.1057/ sub.2010.23.

Mauss, Marcel

1985 "A Category of the Human Mind:The Notion of Person, the Notion of Self." In The Category of the Person: Anthropology, Philosophy, History, edited by Michael Carrithers, Steven Collins, and Steven Lukes, 1-25. New York: Cambridge University Press.

Meadow, Tey Originally published in 1938.

2018 Trans Kids: Being Gendered in the Twenty-First Century. Oakland: University of California Press.

Mehta, Uday Singh

1999 Liberalism and Empire: A Study in Nineteenth-century British Liberal Thought. Chicago: University of Chicago Press.

Menvielle, Edgardo, Catherine Tuerk, and Ellen Perrin

2005 "To the Beat of a Different Drummer: The Gender-Variant Child." Contemporary Pediatrics, Feburary 1. http://www.contemporarypediatrics.com/pediatrics/beatdifferent-drummer-gender-variant-child.

Merleau-Ponty, Maurice

2003 Nature: Course Notes from the College de France. Compiled by Dominique Seglard and translated by Robert Vallier. Evanston, Ill.: Northwestern University Press.

Mol, Annemarie

2002 The Body Multiple: Ontology in Medical Practice. Durham, N.C.: Duke University Press.

Money, John

1955 "Hermaphroditism, Gender, and Precocity in Hyperadrenocorticism: Psychologic Findings." Bulletin of the Johns Hopkins Hospital 96, no. 3: 253-63.

Money, John, J. G. Hampson, and J. L. Hampson

1955 "An Examination of Some Basic Sexual Concepts: The Evidence of Human Hermaphroditism." Bulletin of the Johns Hopkins Hospital 97, no. 4: 301-319.

Najmabadi, Afsaneh

2013 Professing Selves: Transsexuality and Same-Sex Desire in Contemporary Iran. Durham, N.C.: Duke University Press.

Nota, Nienke M., Baudewijntje P. C. Kreukels, Martin den Heijer, Dick J. Veltman, Peggy T.

Cohen-Kettenis, Sarah M. Burke, and Julie Bakker

2017 "Brain Functional Connectivity Patterns in Children and Adolescents with Gender Dysphoria: Sex-Atypical or Not?” Psychoneuroendocrinology 86: 187-95. https://

Plemons, Eric doi.org/10.1016/j.psyneuen.2017.09.014.

2017 The Look of a Woman: Facial Feminization Surgery and the Aims of Trans-Medicine. Durham, N.C.: Duke University Press.

Prosser, Jay

2006 "Judith Butler: Queer Feminism, Transgender, and the Transsubstantiation of Sex." In The Transgender Studies Reader, edited by Susan Stryker and Stephen Whittle, 257-80. New York: Routledge.

Reddy, Gayatri

2005 With Respect to Sex: Negotiating Hijra Identity in South India. Chicago: The University of Chicago Press.

Roen, Katrina

2016 "The Body as a Site of Gender-Related Distress: Ethical Considerations for Gender Variant Youth in Clinical Settings.” Journal of Homosexuality 63, no. 3: 306-322.

Rose, Nikolas https://doi.org/10.1080/00918369.2016.1124688.

1990 Governing the Soul:The Shaping of the Private Self. New York: Routledge. 
Rosenthal, Stephen M.

2014 "Approach to the Patient: Transgender Youth. Endocrine Considerations." Journal of Clinical Endocrinology and Metabolism 99, no. 12: 4379-89. https://doi.

Rubin, Gayle org/10.1210/jc.2014-1919.

1975 “The Traffic in Women: Notes on the 'Political Economy' of Sex." In Toward an Anthropology ofWomen, edited by Rayna Reiter, 157-210. NewYork: Monthly Review Press.

Sadjadi, Sahar

2013 "The Endocrinologist's Office - Puberty Suppression: Saving Children from a Natural Disaster?" Journal of Medical Humanities 34, no. 2: 255-60. https://doi.

Sahlins, Marshall org/10.1007/s10912-013-9228-6.

1976 Culture and Practical Reason. Chicago: University of Chicago Press.

2014 "On the Ontological Scheme of Beyond Nature and Culture." HAU 4, no. 1: 281-90. Salamon, Gayle https://doi.org/10.14318/hau4.1.013.

2010 Assuming a Body: Transgender and Rhetorics of Materiality. New York: Columbia University Press.

Sánchez-Eppler, Karen

1996 "Raising Empires like Children: Race, Nation, and Religious Education." American Literary History 8, no. 3: 399-425. https://www.jstor.org/stable/490150.

Scott, Joan W.

1986 “Gender: A Useful Category of Historical Analysis." American Historical Review 91, no. 5: 1053-75. https://www.jstor.org/stable/1864376.

Snorton, Riley C.

2017 Black on Both Sides: A Racial History of Trans Identity. Minneapolis: University of Minnesota Press.

Spack, Norman P.

2009 "An Endocrine Perspective on the Care of Transgender Adolescents." Journal of Gay and Lesbian Mental Health 13, no. 4: 309-319. https://doi.org/10. 1080/19359700903165381.

Spade, Dean

2006 "Mutilating Gender." In The Transgender Studies Reader, edited by Susan Stryker and Stoller, Robert J. Stephen Whittle, 315-32. New York: Routledge.

1964 "A Contribution to the Study of Gender Identity." International Journal of PsychoAnalysis 45, nos. 2-3: 220-26.

1968 Sex and Gender: On the Development of Masculinity and Femininity. New York: Science House.

Strathern, Marilyn

1988 The Gender of the Gift: Problems with Women and Problems with Society in Melanesia. Berkeley: University of California Press.

Travers, Ann

2018 The Trans Generation: How Trans Kids (and Their Parents) Are Creating a Gender Revolution. New York: New York University Press.

Tsing, Anna

2010 "Worlding the Matsutake Diaspora: Or, Can Actor-Network Theory Experiment with Holism?" In Experiments in Holism: Theory and Practice in Contemporary Anthropology, edited by Otto Ton and Nils Bubandt, 47-66. Malden, Mass.: Blackwell.

Turner, Terence

2012 “The Social Skin.” HAU 2, no. 2: 486-504. https://doi.org/10.14318/hau2.2.026. Originally published in 1980. 
Ulrichs, Karl Heinrich

1994 The Riddle of "Man-Manly"Love: The PioneeringWork on Male Homosexuality. New York: Prometheus Books.

Valentine, David

2007 Imagining Transgender:An Ethnography of a Category. Durham, N.C.: Duke University Press.

Vance, Carole

1989 "Social Construction Theory: Problems in the History of Sexuality." In Homosexuality, Which Homosexuality?, edited by Dennis Altman et al., 13-34. Amsterdam: An Dekker/Schorer.

Vidal, Fernando

2009 "Brainhood, Anthropological Figure of Modernity." History of the Human Sciences 22, no. 1: 5-36. https://doi.org/10.1177/0952695108099133.

Wahrman, Dror

2004 The Making of the Modern Self: Identity and Culture in Eighteenth-Century England. New Haven, Conn.: Yale University Press.

Walters, Suzanna Danuta

2016 The Tolerance Trap: How God, Genes, and Good Intentions Are Sabotaging Gay Equality. New York: New York University Press.

Williams, Thomas Chatterton

2017 "The French Origins of 'You Will Not Replace Us." New Yorker, December 4. https://www.newyorker.com/magazine/2017/12/04/the-french-origins-ofyou-will-not-replace-us.

World Professional Association for Transgender Health (WPATH)

2011 Standards of Care for the Health of Transssexual, Transgender, and Gender Nonconforming People. 7th version. https://www.wpath.org/publications/soc. 